\title{
Relationship between Insurance and Economic Growth in Sub-Saharan African: A Panel Data Analysis
}

\author{
Taiwo Akinlo $^{1 *}$, Olumuyiwa Tolulope Apanisile ${ }^{2}$ \\ ${ }^{1}$ Department of Economics, Adeyemi College of Education, Ondo, Nigeria \\ ${ }^{2}$ Department of Economics, Obafemi Awolowo University, Ile-Ife, Nigeria \\ Email: taiwoakinlo@yahoo.com, mapanisile@oauife.edu.ng
}

Received December 11, 2013; revised January 11, 2014; accepted January 18, 2014

Copyright (C) 2014 Taiwo Akinlo, Olumuyiwa Tolulope Apanisile. This is an open access article distributed under the Creative Commons Attribution License, which permits unrestricted use, distribution, and reproduction in any medium, provided the original work is properly cited. In accordance of the Creative Commons Attribution License all Copyrights @ 2014 are reserved for SCIRP and the owner of the intellectual property Taiwo Akinlo, Olumuyiwa Tolulope Apanisile. All Copyright (C) 2014 are guarded by law and by SCIRP as a guardian.

\begin{abstract}
This study examined the relationship between insurance and economic growth in sub-Saharan Africa over the period 1986-2011. Pooled OLS, Fixed Effect Model and Generalized Method of Moment Panel Model were employed in the estimation. The estimations of the dynamic panel-data results show that insurance has positive and significance impact on economic growth in sub-Saharan Africa. This shows that premium contributes to economic growth in sub-Saharan Africa which means that a well-developed insurance sector is necessary for the economic development, as it provides long-term investments for economic growth and simultaneously strengthening risk-taking abilities. The results also show that human capita has positive significant impact on economic growth. Openness and interest rate have negative and statistical significant on economic growth.
\end{abstract}

\section{KEYWORDS}

Insurance Sector; Economic Growth; Panel Data Analysis

\section{Introduction}

The importance of insurance in trade and development was recognized in the first conference of UNCTAD (1964) where a statement that "a sound National Insurance and reinsurance market is an essential characteristic of economic growth" was made. The importance of the relationship between financial development and economic growth has been well recognized and emphasized in the field of economic development [1]. In fact, financial development is considered as an essential ingredient in any conscious effort to enhance economic development and growth. Recent writings on this subject seem to accept the hypothesis that financial development is crucial for successful economic growth [1].

Insurance is similar to banks and capital market as they serve the needs of business units and private household in financial intermediation. Insurance is a very key part in financial sector. In developed market, the insur-

"Corresponding author. ance sector accounts for a significant portion of the economy. In collecting relative premium from many small individuals in the economy, insurance is able to pull together like none other institutions, a large pool of funds that could be invested in both short and long term periods. Insurance businesses are split mainly into Nonlife, Life and Re-insurance; Non-life insurance represents short term funds and Life represents long term funds while Re-insurance indemnifies other insurance company against loss. As so many insurers could serve as the means of long term financing, the sector is therefore important for sustained economic growth. This will in turn deepen and broaden the domestic services, and generate higher saving rate and therefore greater economic development. Insurance is critical to the ability of emerging and transition economies like Nigeria to grow, develop and provide a reliable cover for risk to the citizens. Insurance provides stability by allowing large and small businesses to operate with a lesser risk of volatility or failure [2]. 
Insurance serves a number of valuable economic functions that are largely distinct from other types of financial intermediaries. In order to highlight specifically the unique attributes of insurance, it is worth focusing on those services providers, excluding for instance the contractual savings features of whole or universal products. The indemnification and risk pooling properties of insurance facilitate commercial transactions and the provision of credit by mitigating losses as well as the measurement and management of non-diversifiable risk more generally. Typically, insurance contracts involve small periodic payments in return for protection against uncertain, but potentially severe losses. Among other things, this effect of income smoothing helps to avoid excessive and costly bankruptcies and facilitate lending to businesses. Most fundamentally, the availability of insurance enables risk-averse individual and entrepreneur to undertake higher risk, higher returns activities than what they would do in the absence of insurance, promoting higher productivity and growth [3].

In view of the importance or role of insurance in the growth process, several empirical studies have been undertaken on its impact on growth. However, no consensus has emerged on the impact of insurance development and economic growth. For example, studies such as Ćurak et al. [4], Haiss and Sumegi [5], Arena [6], and Pen-Fen et al. [7] found that insurance had positive impact on economic growth. However, study by Webb et al. [8] showed that insurance had no significant positive effect on economic growth. The number of empirical studies is relatively small (for survey sees Levine [9]; Thiel, [10]; Ang, [11]). Indeed, most existing studies on insurance-growth nexus are focused on the developed and few industrializing countries. In sub-Saharan Africa, not many studies have focused on the insurance sector probably due to the small size of the sector before the reforms in the early 80s. Indeed, only few studies to our knowledge have been published on the insurancegrowth nexus in Sub-Sahara Africa. These are no doubt big gaps in the literature which need to be filled. It is important to inquire into not only the growth of the insurance sector in sub-Saharan Africa but also how the sector has impacted economic growth. This is why the main objective of this article is to examine the relationship between insurance and economic growth in sub-Saharan Africa.

The rest of the paper is structured as follows: first, we provide an overview of the insurance sub-sector in subSaharan Africa. Second, summary of the empirical studies on the impact of insurance on economic growth is discussed. Third, we discuss the methodology adopted in the work and then provide the empirical results. The last section contains the concluding remarks.

\section{Overview of Insurance in Sub-Saharan Africa}

The sub-Saharan Africa countries has a combine population of 780 million is which is the ninth population of the world in 2011. With this population one might expect the sub-Saharan African to be one of the largest markets for insurance but the insurance sector only account for $0.2 \%$ of total world premium. The insurance penetration (premium as percentage of GDP) in sub-Saharan is very low compare to other regions of the world. According to Swiss Re [12] between 2000 and 2011 the average growth rate of insurance premium in sub-Saharan Africa is 7.1\% annually and in 2011 it reached about 8.9 billion USD. The oil producing countries and middle countries experienced the highest growth of premium in sub-Saharan Africa. Based on Swiss Re report the six largest markets for insurance in Africa are South Africa, Nigerian Kenya, Angola, Namibia and Mauritius. These six countries have a combine market of $68 \%$. The little fact provided shows that the SSA insurance markets sub-Saharan Africa are in a typical early phase of development, where the main focus lies on commercial lines of business in non-life and group business in life. Insurance penetration in SSA is very below the other regions of the world. However, it is only life insurance that is below expectation given the current level of income in Sub-Saharan Africa. Motor and business line related to the extraction of gas, oil and other renewable resources dominated while the personal non-life accounted for low percentage. The situation is not different in life insurance as individual take up of personal life insurance is very low while the group business dominates.

Life insurance premiums in Africa are estimated to have increased by a strong $14 \%$ to USD 50 billion in 2012, compared to $2.9 \%$ in 2011 . South Africa, the region's dominant market, accounts for around $90 \%$ of regional life premium volume. In South Africa premiums were up by 14\% in 2012, compared to 2.9\% in 2011. Growth was supported by increases in new policies as well additions to the recurring premiums for individual in-force policies. Retirement annuities also buoyed growth in both single as well as recurring premiums. Elsewhere in Africa, data availability is very limited for 2012. Premiums in Algeria, the ninth largest market, are estimated to have declined by $6.4 \%$ in 2011 . In other countries in the region, the latest available data for 2011 suggests that premium volumes have expanded in the majority of African countries.

Non-life premiums in Africa are estimated to have shrunk by $1 \%$ in 2012, driven by the largest market, South Africa, where premiums shrank by $1.4 \%$ in 2012 (2011: +4.3\%). Exposure growth was muted as economic activity slowed from weaker exports to Europe, a key market for South Africa. Premium rates were also re- 
strained by intense competitive pressure as new entrants sought to attract business with low prices. Elsewhere in Africa, Algeria one of the few countries with data for 2012 recorded moderate growth of $3.2 \%$.

Comparing Africa with other regions, the total Africa insurance premium in 2009 is 57453 millions USD. While in 2010 and 2011 the total premium was 63072 million and 68080 million respectively which is just $1.54 \%$ and 1.48 share of the total world market in 2010 and 2011. At this particular time in other region, the total insurance premium of Asia in 2009 was 1014419 million USD, which make up of $26.76 \%$ of the world market share. At this same period in America the total premium was 1.357559 million USD which is $32.49 \%$ of world share. The total premium of Asia in 2010 and 2011 are 1172176 million USD and 1298139 million USD respectively. The total premium of America in 2010 and 2011 are 1615190 million USD and 1650866 million USD respectively. The breakdown of insurance volume by region is provided in the Figure 1 below.

From the figure above it is shown clearly that total Africa premium is the least comparing to other region of the world. This shows clearly that insurance is in early development in Africa. The Figure 2 below shows the volume of premium as percentage of GDP in Africa and other region. In Africa the insurance premium only make up of $4 \%$ of the GDP in 2007 while at that particular time in Europe it was $8 \%$ and $7.5 \%$ of total GDP in America. In 2008 the contribution of insurance to GDP has fallen to $1.2 \%$ in Africa this might connected to economic melt down in 2008 as insurance premium contribution to GDP in other region also fall at that particular period. The percentage contribution of insurance to GDP was highest in Africa in 2010.

Figure 3 below shows insurance penetration in Africa from 2003 to 2012. A critical examination of this figure shows that insurance penetration in Africa is very low compare to other regions. For example in 2003 insurance in Africa only contributes only $1.13 \%$ to the world total penetration which is the least in the world. But there is significant increase in insurance penetration in 2004 as Africa accounted for $8.64 \%$ of the world total penetration. A further examination of Figure 3 shows clearly that insurance penetration is unstable over the years as it goes up and down probably due to prevailing economic situations. But Africa insurance penetration is significantly improving as it recorded the highest penetration in 2010.

The African insurance market has strong growth potential, especially in sub-Saharan Africa, driven by economic activity which will boost demand for insurance. Life insurance penetration in sub-Saharan Africa, though still very low, is increasing gradually along with rising awareness of the usefulness of insurance, efforts by insurance companies to expand their presence by intro-

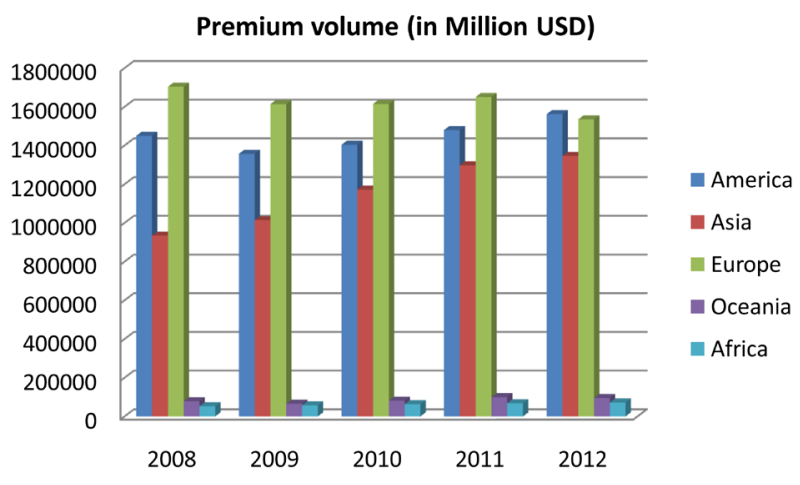

Figure 1. Premium volume (in million USD).

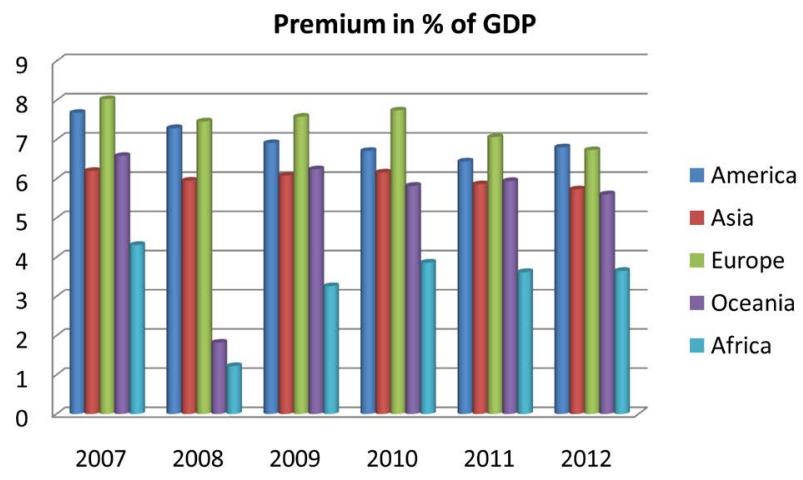

Figure 2. Premiums in \% of GDP.

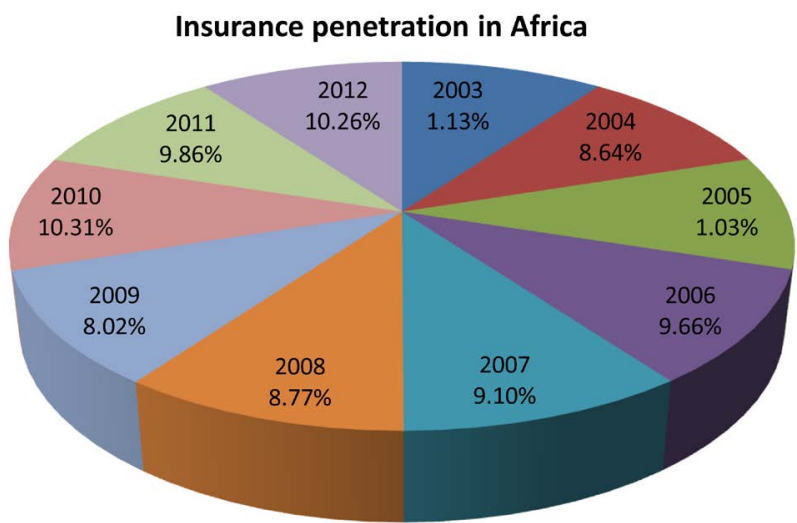

Figure 3. Insurance penetration in Africa.

duceing micro-insurance and Takaful, and also through alternative distribution channels. In South Africa, premium growth is likely to be sustained by increases in annuity sales.

\section{Review of Empirical Literature}

Several studies have been conducted to examine the nature of the relationship between insurance and economic growth in the developed countries and other region of the world. However, in sub-Saharan Africa not many studies have been conducted on the subject matter. In this sub- 
section, we provide a summary of the findings of the existing studies on the relationship between insurance and economic growth mostly literatures done on developed countries due to few studies done on this topics in Africa.

Beenstock, Dickinson and Khajuria [13] applied pooled times series and cross-section analysis on 1970-1981 data, covering mainly 12 countries. They regressed premiums for property liability insurance on gross national product, income and interest rate development. They found that premiums are correlated to interest rate and GNP; marginal propensity to insure (short and long-run) rises with income per capita and higher in long run. Beenstock et al. [12] argue that insurance consumption is not affected by economic cycles or cyclical income variation.

Browne, Chung and frees [14] applied a pool crosssectional panel model to motor vehicle and general liability insurance in the OECD over the 1986-1993 period. They regressed liability insurance on a variety of factors including income, wealth and the legal system. Income and the legal system were positively correlated to insurance consumption, while loss, probability and wealth were negatively correlated with insurance consumption. Foreign firms in the market and risk aversion were positively related to motor vehicle insurance consumption and hence contrary to general liability consumption. The correlation with risk aversion is statistically insignificant for motor vehicle insurance consumption and negatively connected in the cross-sectional model for general liability insurance consumption.

Kugler and Ofoghi [15] examine long run relationship between insurance market size and economic growth in United Kingdom for the period from 1966 to 2003 for long-term insurance, and from the period 1971 to 2003 for general insurance (from 1991 to 1997 for marine aviation transport insurance and reinsurance). In comparison to Ward and Zurbruegg [16], who used aggregate variable in their estimation (total written premium) due to possibility of co-integration. They used disaggregated data for the measure of market size. Namely, net written premium for each market in insurance industry in the United Kingdom is used as a measure of market size for that market. The market is divided into long-term insurance market, that includes life insurance, annuities, individual pensions and other pensions, and general business insurance market including motor, accident and health, liability, property, pecuniary loss, marine aviation and transport insurance and reinsurance. Using Johansen's co-integration test the authors found a long relationship between development in insurance market size and economic growth for all components of insurance market. Causality in short run exists from life, life and pecuniary loss insurance to economic growth. There is evidence of bidirectional causal relationship in the long run between economic growth and insurance market size for the three insurance categories, with more powerful causality running from economic growth to insurance development than causality from the other direction.

Haiss and Sumeji [5] investigated both the impact of insurance investment and premiums on GDP growth in Europe and conducted a cross-country panel data analysis from 1992 to 2005 for 29 European countries. They found a positive impact of life insurance on GDP growth in $15 \mathrm{EU}$ countries, among which were Switzerland, Norway and Iceland. For the New EU Member States from Central and Eastern Europe, they found a larger impact for liability insurance. Furthermore their findings emphasized the impact of the real interest rate and the level of economic development on the insurance-growth nexus. They argued that the insurance sector needed to be paid more attention in financial sector analysis and macroeconomics policy.

Krishna [17], after examining the rapid growth of the insurance sector in the post-liberalization period and seeing it as a good sign as it could facilitate investment in infrastructure development to help sustain the economic growth of the country. Against this backdrop, he raised an important question: what had been the contribution of insurance sector growth to economic development in India? He further examined the economic growth effects of insurance sector reforms and the rate of growth of insurance reforms. However, his claims were mixed. According to him, the contribution of the insurance sector to economic development was positive and exhibited a long-run equilibrium relationship. He discovered that the reforms exerted no strong relationship but the rate of growth of reforms had a positive influence on economic development. He therefore suggested that in order to make the insurance sector a more important component of the financial intermediation process, complete deregulation and an increase in the pace of reforms were the need of the hour.

\section{Methodology}

This study adopted the endogenous growth model with a modified Cobb-Douglass production function. This approach has been adopted by several authors including Eller et al. [18], Fink et al. [19] and Webb et al. [8]. Aggregate output is specified as:

$$
Y_{i t}=A K_{i t}^{\alpha} H_{t}^{\beta} L_{i t}^{1-\alpha-\beta}
$$

where $Y$ represents the output (GDP), A denotes technology progress, $\mathrm{K}$ represents physical capital, $\mathrm{H}$ stands for human capital and finally $\mathrm{L}$ is the used labour force. After transforming Equation (3.5) into the intensive form, it becomes:

$$
y_{i t}=A k_{i t}^{\alpha} h_{i t}^{\beta}
$$


By taking logarithm of both sides and differentiating EQuation (2)

$$
\Delta \ln \left(y_{i t}\right)=\ln (A)+\alpha \Delta \ln \left(k_{i t}\right)+\beta \Delta \ln \left(h_{i t}\right)
$$

To incorporate insurance into Equation (3), $\ln \left(k_{i t}\right)$ is decomposed into two separately observable parts as argued by Haiss and Sumegi [5]. According to them, premiums collected by insurance companies are a flow variable and they resemble an input factor which influences the performance of physical capital. Therefore, the accumulation of premiums can be transformed into assets which add to their physical capital. This increases their capital base and encourages further investment. Therefore, physical capital can be decomposed into premium and capital:

$$
\Delta \ln \left(k_{i t}\right)=\Delta \ln P R E M_{i t}+\Delta \ln \left(k_{f}\right)
$$

By substituting Equation (3.8) into Equation (3.7), it becomes:

$$
\begin{aligned}
\Delta \ln \left(y_{i t}\right) & =\ln (A)+\alpha_{1} \Delta \ln \left(\operatorname{PREM}_{i t}\right) \\
& +\alpha_{2} \Delta \ln \left(k_{f}\right)+\alpha_{3} \Delta \ln \left(h_{i t}\right)
\end{aligned}
$$

where PREM represents insurance premium, $k_{f}$ represents financial capital, h represents human capital, A represents technology and y represents economic growth.

Apart from the financial and investment factors, evidence from previous studies has shown that many other factors are significant determinants of real growth. Peter and Kjell [20] found interest rate to be one of such factors, while Liyan, Donghui, Fariborz and Yanhui [21] took account of inflation and Arena [6] included openness in his study.

$$
\begin{aligned}
\Delta \ln \left(y_{i t}\right) & =\ln (A)+\alpha_{1} \Delta \ln \left(\text { PREM }_{i t}\right) \\
& +\alpha_{2} \Delta \ln \left(K_{f}\right)+\alpha_{3} \Delta \ln \left(h_{i t}\right)+\alpha_{4} \Delta \ln \left(I N F_{i t}\right) \\
& +\alpha_{5} \Delta \ln \left(I N T_{i t}\right)+\alpha_{6} \Delta \ln \left(\text { OPEN }_{i t}\right)+e_{i t}
\end{aligned}
$$

where all the variables are as defined above and $\alpha_{1}, \alpha_{2}$, $\alpha_{3}, \alpha_{4}, \alpha_{5}$ and $\alpha_{6}$ are coefficients of premium, capital, human capital, inflation, interest rate and openness respectively $e_{t}$ is the disturbance term.

The role of insurance in an economy includes mobilization of domestic fund, managing risk, mitigating loses, and other functions which stimulate economic growth. If these functions are effectively performed in the economy, the level of investment will definitely rise. In this wise, there should be positive relationship between insurance and economic growth and $\alpha_{1}$, is expected to be positive.

Physical capital accumulation plays important role in economic growth of any nation. Physical capital accumulation occurred as a result of investment. Physical capital in form of infrastructure such as good transporta- tion network and stable power supply is capable of stimulating economic growth. Therefore, the coefficient $\alpha_{2}$, is expected to be positive.

Inflation reduces real returns to saving sand, through this mechanism, exacerbates an informational friction afflicting the financial system. This financial market friction might result to credit rationing and thus limit the availability of investment capital (the level of investment) and reduce the efficiency of the allocation of savings to investment projects (the efficiency of investment), and finally adversely affect the long-run economic growth. So $\alpha_{4}$, is expected to be negative.

Interest rates play a key role in economic growth. Low, stable interest rates encourage investment. In the short run, investment creates increased aggregate demand, but in the long run it expands the economy's stock of capital. High interest rates or unstable interest rates are injurious to investment decisions and result in the formation of less capital. The coefficient of interest rate is expected to be negative.

\section{Measurement of Variables and Data Source}

Panel data will be used for the empirical analysis. This data is from selected sub-Sahara Africa countries and covered the period of thirty one years (1986-2011). We choose countries in the sample on the basis of data availability, giving us a total of thirty sub-Saharan African countries out of a possible forty-seven. These countries includes Benin, Botswana, Burkina Faso, Cameroun, Cape verde, Central Africa Republic, Chad, Congo, Cote d'ivore, Democratic of Congo, Gabon, Gambia, Ghana, Guinea-Bissau, Kenya, Lesotho, Mozambique, Malawi, Mali, Namibia, Niger, Nigeria, Rwanda, Senegal, Swaziland, Sierra Leone, South Africa, Togo, Uganda and Zambia. Unless otherwise stated, data on all variables is obtained from UNCTAD Statistics, a database maintained by the United Nations Conference on Trade and Development.

The following variables were used. The dependent variable in this study is the percentage growth of GDP. For consistency, we use real GDP measured in current US dollars across the sample. The key independent variable is the Gross premium income which is measured by total sum of premium income from life and non-life insurance business. Physical capital is measured by gross fixed capital formation as a percentage of GDP. Human capital is measured by the total work force. Inflation is the log difference of composite consumer price indices, Interest rate (INT) is proxies by deposit interest rate and Openness is measured by the sum of import and export as percentage of GDP. Due to missing data on premium in some of the series (especially Mali, Gambia), some minor gaps have been filled by interpolation. 


\section{Empirical Results}

We begin the analysis of the relationship between insurance and economic growth in sub-Saharan Africa with descriptive analysis. The report of the descriptive statistics of the variables from 1986-2011 are reported in Table 1 below. The descriptive statistics shows that all the series shows a high level of consistencies as all the mean and median fall within the maximum and minimum values of these series. The descriptive statistics also reveal that the growth rate of insurance premium is very low as the average growth rate is $5.96 \%$. Considering the standard deviation (S.D) which measures the level of variation or degree of dispersion of the variables from their mean reveals that the actual deviation of the data from their means are very small as all the standard deviations are very low. This also shows that insurance premium is more stable compare to other variables. The most volatile is the interest rate (8.66\%) while the least volatile is the openness $(0.44 \%)$ follow by insurance premium (0.95\%). Finally, variables like GDP, premium, physical capital, interest rate and inflation are leptokurtic (peaked) relative to the normal as kurtosis of this series exceeds three. However, human capital and openness are not as their kurtoses are below three.

To examine the possible degree of association among the variables the correlation matrix were obtained. Table 2 below presents the correlation matrix of the variables used in the study. The directions of relationship are revealed by the correlation table. Generally, the results in Table 2 show that premium is positively correlated with the GDP. The coefficient is 0.2082 . This positive relationship between GDP and premium shows that any increase in premium will lead to economic growth. The correlation matrix also shows that there is positive relationship of human capital, interest rate with GDP. But physical capital, inflation and openness has negative relationship with GDP. Openness on the other hand has positive relationship with premium. The correlation matrix also reveals that variables such as human capital, physical capital, inflation and interest rate has negative on premium.

Three forms of functional estimation were used in order to determine the relationship between insurance and economic growth, three forms of used; the pooled ordinary least square, the fixed effect model and generalized moment method (GMM) estimation. The results of the pooled OLS, fixed effect and GMM are presented in Table 3 below. The pooled OLS results show the variables that are statistically significant and those that are not significant. The explanatory power of the fixed effect result is higher. The adjusted $R^{2}$ of pooled OLS is 0.58 while that of fixed result is 0.99 . The F-statistics is statistically significant in all the models. The results indicate that insurance premium is positive in two of the models and significant in one model. We can deduce from this results that on the short run insurance premium might not have positive significant effect on economic growth but on the long run insurance will have positive and significant relationship with economic growth. Human capital has positive and statistical significant at $1 \%$ under pooled OLS and this is confirm by GMM results which serve as robust check. The coefficient is 1.2269 under pooled and 0.1254 under GMM. This result implying that human capital has positive relationship with economic growth. This is probably due to the role of human capital in improving the quality of life and ensuring social and economic progress and also helping the developing country to absorb modern technology and to develop the capacity for self-sustaining growth and development. Physical capital is negative under pooled OLS and fixed model but statistically significant at $1 \%$ under pooled OLS and at $5 \%$ under GMM. The coefficient of inflation is positive and statistically insignificance under Pooled this results is also confirmed by GMM estimation. This result of positive inflation is consistent with the result of Haiss and Sumegi [5]. Interest rate has negative relationship with economic growth and significant at $1 \%$ in both pooled and fixed estimation. These results are also confirmed by GMM estimation which serves as robust check. This result is in line with theoretical inverse relationship. Openness is negative and statistically significant at $1 \%$ in two models. This means that sub-Saharan Africa countries needs to open there economies more so that the inflow of foreign direct investment can increase and thereby enjoying the benefits of openness.

\section{Summary and Conclusion}

The aim of this study is to examine the relationship between insurance and economic growth in sub-Sahara Africa from 1986-2011. We provided the overview of insurance sector in Sub-Saharan Africa by examining insurance penetration, insurance premium volume in Africa compared to the rest of the world, premium as a percentage of GDP and contribution of insurance to the total world premium. We started our analysis with descriptive analysis. The descriptive statistics table was presented, the correlation matrix, and the results of the three methods of estimation were also presented.

The empirical analysis of a panel data set of 30 subSaharan African countries for the period from 1986 to 2011 is used to estimate the coefficients and the significance of each input factor, but results showed that insurance premium is positive in two of the estimations and statistically significance in pooled OLS. This means that insurance premium has positive and significant impact on economic growth in sub-Saharan Africa. It is therefore recommended that the policies that will improve insurance market penetration through developing the supply 
Table 1. Descriptive statistics.

\begin{tabular}{cccccccc}
\hline & GDP & PREM & HUM & PHY & INF & INT & OPEN \\
\hline MEAN & 21.72728 & $5.96 E-05$ & 14.80915 & 3.939686 & 1.901508 & 9.483864 & 4.18769 \\
MEDIAN & 22.14882 & -0.105361 & 15.00630 & 3.015072 & 1.995262 & 7.000000 & 4.17982 \\
MAXIMUM & 26.71923 & 2.884242 & 17.74752 & 20.88830 & 10.07631 & 60.00000 & 5.34650 \\
MINIMUM & 5.262122 & -4.605170 & 11.67844 & -1.228027 & -3.305445 & 2.433333 & 2.97981 \\
STD.DEV & 3.184657 & 0.950079 & 1.325929 & 3.710772 & 1.306669 & 8.664753 & 0.44329 \\
SKEWNESS & -3.806936 & 0.482352 & -0.191727 & 3.416840 & -0.070349 & 2.842218 & 0.08356 \\
KURTOSIS & 20.18434 & 4.922395 & 2.421547 & 13.38288 & 7.679219 & 13.03347 & 2.61602 \\
JARQUE-BERA & 8139.990 & 106.5967 & 11.09789 & 3560.016 & 504.9556 & 3064.156 & 4.04086 \\
PROBABILITY & 0.000000 & 0.000000 & 0.003892 & 0.000000 & 0.000000 & 0.000000 & 0.13259 \\
SUM & 12015.18 & 0.032971 & 8189.462 & 2178.646 & 1051.534 & 5244.577 & 2315.79 \\
SUM SQ DEV & 5598.408 & 498.2627 & 970.4640 & 7600.947 & 942.4766 & 41443.03 & 108.472 \\
OBSERVATION & 553 & 553 & 553 & 553 & 553 & 553 & 553 \\
\hline
\end{tabular}

Table 2. Correlation matrix.

\begin{tabular}{|c|c|c|c|c|c|c|c|}
\hline & GDP & PREM & HUM & PHY & INF & INT & OPEN \\
\hline GDP & 1.000000 & & & & & & \\
\hline PREM & 0.208277 & 1.000000 & & & & & \\
\hline HUM & 0.277250 & -0.058152 & 1.000000 & & & & \\
\hline PHY & -0.571444 & -0.114299 & 0.279494 & 1.000000 & & & \\
\hline INF & -0.015981 & -0.017645 & 0.146438 & 0.095132 & 1.000000 & & \\
\hline OPEN & -0.099754 & 0.128478 & 0.125230 & 0.057246 & -0.053697 & -0.096150 & 1.000000 \\
\hline
\end{tabular}

Table 3. Panel data estimates.

\begin{tabular}{cccc}
\hline Variables & Pooled OLS Result & Fixed effect & GMM \\
\hline C & $10.7518^{* * * *}$ & $22.9938^{* * *}$ & \\
GDP(-1) & $(8.6978)$ & $(7.0872)$ & \\
& & & $0.7552^{* * *}$ \\
PREM & $0.5970^{* * * *}$ & -0.0343 & 0.0173 \\
& $(6.3472)$ & $(-1.5303)$ & $(0.3324)$ \\
HUM & $1.2269^{* * *}$ & -0.1143 & $0.1254^{* * *}$ \\
& $(17.3139)$ & $(0.5133)$ & $(4.9970)$ \\
PHY & $-0.5874^{* * *}$ & -0.0043 & $0.0667^{* *}$ \\
& $(-23.5848)$ & $(-0.1619)$ & $(1.9658)$ \\
INF & 0.0344 & $-0.0276^{* * *}$ & 0.0025 \\
& $(0.4301)$ & $(-2.8372)$ & $(0.3324)$ \\
INT & $-0.0307^{* * * *}$ & $-0.0046^{* * *}$ & $-0.0038^{* * *}$ \\
& $(-2.5250)$ & $(-2.7881)$ & $(-3.4762)$ \\
OPEN & $-1.1115^{* * *}$ & $0.1286^{* * *}$ & -0.0010 \\
$R^{2}$ & $(-5.4667)$ & $(5.2168)$ & $(-0.0242)$ \\
Adjusted $R^{2}$ & 0.58 & 0.99 & \\
F-Statistics & 0.57 & 0.99 & \\
D-Watson stat & 127.92 & 2549.92 & \\
J-Statistics & $(0.0000)$ & $(0.0000)$ & \\
No of Observation & 0.042 & 0.44 & \\
Cross section & & & 27.05 \\
Included & 553 & 553 & 522 \\
\hline
\end{tabular}

denote significant at $1 \%,{ }^{* * *}$ significant at $5 \%$. chain to capture the critical mass population should be adopted in sub-Saharan Africa. The lack of confidence of average person in insurance can be reduced by removing the suspicion that claims would not be paid, which limits growth of the insurance market in Nigeria as they have to improve their business practice in this regard. On the part of insurance companies they should use seminar, conferences, and advertisement to create public awareness for their products and other policies aiming at massive education of insurance consumers on the importance of buying insurance products should also be put in place.

This study found negative relationship between physical capital and economic growth in sub-Saharan Africa. This can be reversed if the sub-Saharan Africa leaders can embark on developmental policies aiming to increase the physical capital stock of the nation with investment in social and economic infrastructure and adopt the policies of diverting resources from consumption expenditure to infrastructure development. Infrastructures such as good roads, electricity, health facilities will accelerate the development of insurance sector in the country. The negative and statistical relationship found between economic growth and openness shows that sub-Africa government need to open more economies so as to allow foreign direct investment to flow in and also for foreign insurance companies to come in. 


\section{REFERENCES}

[1] H. J. Yousuf, "The Economic Significant of the Insurance Sector in Kuwait," Journal of Economic and Administrative Science, No. 14, 1998, pp. 107-124.

[2] B. Akanro, "The Insurance Industry Vs Nigeria Economy, Light Does Not Shine in Light,” 2008.

[3] L. Brainard and B. L. Schwartz, "What Is the Role of Insurance in Economic Development?” Zurich Financial Services, Zurich, 2008.

[4] M. S. Curak, Loncar and K. Poposki, "Insurance Sector Development and Economic Growth in Transition Countries," International Research Journal of Finance and Economics, Vol. 34, No. 1, 2009, pp. 29-41.

[5] P. Haiss and K. Sumegi, "The Relationship of Insurance and Economic Growth in Europe: A Theoretical and Empirical Analysis," Empirical, Vol. 35, No. 4, 2008, pp. 405-431. http://dx.doi.org/10.1007/s10663-008-9075-2

[6] M. Arena, "Does Insurance Market Activities Promote Economic Growth? A Cross-Country Study of Industrialized and Developing Countries,” World Bank Policy Research Paper 4098, 2006, pp. 1-3.

[7] P.-F., Chen, C.-C. Li and C.-F. Chen, "How Does the Development of the Life Insurance Market Affect Economic Growth? Some International Evidence,” Journal of International Development, Vol. 24, No. 7, 2011, pp. 865-893.

[8] I. P. Webb, M. F. Grace and H. D. Skipper, "The Effect of Banking and Insurance on the Growth of Capital and Output," Centre for Risk Management and Insurance Working Paper No. 02-1, Robinson College of Business, Georgia State University, Atlanta, 2002.

[9] R. Levine, "Financial Development and Economic Growth: Views and Agenda," Journal of Economics Literature, Vol. 35, No. 2, 1997, pp. 688-726.

[10] M. Thiel, "Finance and Growth-A Review of Theory and Available Evidence,” European Commission Working Paper No. 158, 2001, 50 p.

[11] J. B. Ang, "A Survey of Recent Developments in the Literature of Finance and Growth," Journal of Economic Surveys, Vol. 22, No. 3, 2008, pp. 536-576. http://dx.doi.org/10.1111/j.1467-6419.2007.00542.x
[12] Swiss Re Sigma, “World Insurance in 2012,” 2013.

[13] M. Beenstock, G. Dickinson and S. Khajuria, "The relationship between Property-Liability Insurance Penetration and income: An International Analysis," The Journal of Risk and Insurance, Vol. 55, No. 2, 1998, pp. 259-272. http://dx.doi.org/10.2307/253327

[14] M. J. Browne, J. W Chung, and E. W. Frees, "International Property-Liability Insurance Consumption,” The Journal of Risk and Insurance, Vol. 67, No. 1, 2000, pp. 73-90. http://dx.doi.org/10.2307/253677

[15] M. Kugler and R. Ofoghi, "Does Insurance Promote Growth? Evidence from the UK," Working Paper, University of Southampton, Southampton, 2005.

[16] D. Ward and R. Zurburegg, "Does Insurance Promote Economic Growth? Evidence from OECD Countries," Journal of Risk and Insurance, Vol. 67, No. 4, 2000, pp. 489-506. http://dx.doi.org/10.2307/253847

[17] C. T. Krishna "Do Insurance Sector Growth and Reforms Affect Economic Development? Empirical Evidence from India," The Journal of Applied Economic Research, Vol. 2, No. 1, 2008, pp. 43-86.

[18] M. Eller, P. Haiss and K. Steiner, "Foreign Direct Investment in the Financial Sector: The Engine of Growth for Central and Eastern Europe?” IEF Working Paper No. 70, Research Institute for European Affairs, University for Economics and Business Administration Vienna, 2005, http://fgr.wuwien.ac.at/institut/ef/nexus.html

[19] G. Fink, P. Haiss and S. Hristoforova, "Credit, Bonds and Stocks in Seven Large Economies,” 16th Asian Finance Association Conference (AsianFa) on "Role of Capital Markets in Wealth Creation and Prosperity", Kuala Lumpur, July 2005, Asian FA 2005 Conference CD Paper No. 29. http://fgr.wuwien.ac.at/institut/ef/nexus.html

[20] P. R. Haiss and K. Sümegi, "The Relationship of Insurance and Economic Growth, A Theoretical and Empirical Analysis," Journal of Applied Economics and Economic Policy, Vol. 35, No. 4, 2008, pp. 405-431.

[21] L. Y. Han, D. H. Li, F. Moshirian and Y. H. Tian, "Insurance Development and Economic Growth,” The International Association for the Study of Insurance Economics, 2010. 